\title{
Eucalyptus fastigata: its current status in New Zealand and breeding objectives for the future
}

\author{
By S. K. Kennedy*), H. Dungey, A. D. Yanchuk and C. B. Low \\ Scion, 49 Sala Street, Private Bag 3020, Rotorua, New Zealand
}

(Received $31^{\text {th }}$ January 2011)

\begin{abstract}
Eucalyptus fastigata is currently the most promising species of eucalypt planted in New Zealand due to its better disease resistance and wood machinability. A breeding programme for E. fastigata was established in New Zealand in 1979 with the planting of a progeny/provenance trial series containing material collected from native Australian provenances and $2^{\text {nd }}$ generation local land race material from New Zealand and South African populations. A second series containing additional Australian and South African material was planted in 1994.

Landrace material from New Zealand did not perform well compared to Australian and South African populations, suggesting early introductions to New Zealand originated from poor seed sources and/or suffered from inbreeding. Analysis of these trials has provided base genetic parameters for this species providing direction for the next generation of the breeding programme. Predicted genetic gains of $15 \%$ for tree form and diameter for the 1979 series, and gains of $8 \%$ for diameter and $12 \%$ for malformation for the 1994 series, indicate the potential for increases in both tree form and growth rate.
\end{abstract}

Key words: Eucalyptus fastigata, Heritability, Genetic correlation.

\section{Introduction}

Eucalyptus fastigata occurs naturally along a narrow strip adjacent to the New South Wales coast, Australia, extending from latitude $30^{\circ} 30^{\prime}$ to $37^{\circ} 20^{\prime}$ 's (ELDRIDGE et al., 1993). The species has an altitudinal range typically between 700 and $1200 \mathrm{~m}$, and prefers moist, fertile, welldrained soils. The mean annual rainfall of the natural range of $E$. fastigata is between 800 and $2000 \mathrm{~mm}$, distributed fairly uniformly throughout the year (ELDRIDGE et al., 1993). The northern-most $E$. fastigata provenances of Oberon and Barrington Tops can tolerate frosts of $-9^{\circ} \mathrm{C}$ (WILCOX, 1982).

First planted in New Zealand in the 1880's E. fastiga$t a$ was successfully grown on many farm sites, especially around the Central North Island (WILCOX, 1980). Eucalyptus fastigata was found to grow well throughout New Zealand and is one of the healthiest and most adaptable species of Eucalyptus tested. Eucalyptus fastigata displays considerable promise in New Zealand for both timber and pulpwood production (Jones et al., 2010). The main drawback of $E$. fastigata as a commercial species is

\footnotetext{
*) Corresponding author: S. K. KenNEDY.

E-Mail: stuart.kennedy@scionresearch.com.
}

the tendency for its crown to break up early into rough, heavy branches and competing leaders (WILCOX, 1980). Eucalyptus fastigata is seen as a minor species in Australia with little commercial importance. However, it has been identified as being of greater value in South Africa and New Zealand where breeding programmes have been established to improve the growth and form of the species. A genetic improvement programme for $E$. fastigata was set up in New Zealand in 1977 as part of a wider programme looking at seven different species of Eucalyptus (WILCOX, 1980).

The initial E. fastigata trial series planted in 1979 tested a range of material selected from New Zealand stands of unknown origin and native Australian provenances. Plus-tree selection required trees to have fine branching, good stem form, rapid growth and adequate frost tolerance. Only five provenances from New South Wales (NSW), Australia were represented adequately for the estimation of genetic parameters (i.e., a number of other provenances from Australia were planted, but were only represented by one family each and/or by bulked seedlots). This material was considered of insufficient size to form a future breeding population, therefore, a second trial series was established to evaluate: i) native Australian provenances from NSW, ii) South African landrace families selected from plantations in Eastern Transvaal and from Mondi Forest, and iii) 60 families derived from forward selection in a seedling seed orchard at Jessievale, South Africa. Although there have been active breeding programmes for $E$. fastigata in New Zealand and South Africa since the 1970's, little information about the genetics of this species has been reported in the literature.

The objectives of this paper are to: 1. Provide genetic parameters for the New Zealand E. fastigata breeding populations; 2. Compare the native selections from Australia to the $2^{\text {nd }}$ generation local land race selections from New Zealand and South Africa; 3. Identify the provenance(s), families and individual selections best suited to growth in New Zealand, and; 4. Quantify the current genetic gain levels expected from these 'forward' selections.

\section{Methods}

\section{Trials and measurements}

\section{9 trial series}

In 1979 , progeny tests comprising 126 open-pollinated families were established at two sites in New Zealand's North Island, Kinleith (38 $17^{\prime}$ S $\left.176^{\circ} 00^{\prime} \mathrm{E}\right)$ and Kain- 
garoa $\left(38^{\circ} 27^{\prime} \mathrm{S} 176^{\circ} 42^{\prime} \mathrm{E}\right)$ (Table 1 ). Of these 126 families, eleven were composite families made up by bulking seed from several mother trees. Both trials were SingleTree-Plot (STP) randomised complete block designs. Families were divided equally into three sets of 42 , sets were replicated 36 times at Kinleith and 42 times at Kaingaroa. The three 42 tree sets were grouped together within replicates at each site. The use of sets was adopted for convenience of handling and measurement, with each set containing roughly equal representation of provenances. Forty eight of the families were from local plus trees (detailed in WILCOX, 1982), 73 from various native Australian provenances and 6 families were from South Africa.

One year after planting, frost damage and height growth were assessed at Kinleith and 4 months later incidence of forking was assessed at both sites; results were presented and discussed by WILCOX (1982). These trials were also assessed at age five for diameter at breast height (DBH), stem form, stem straightness and height and again at age 11 for $\mathrm{DBH}$ and stem form (Table 2). A Smith-Hazel index for $\mathrm{DBH}$ and form traits was used in the initial analysis to select the best families and the best individuals within these families for inclusion in the breeding population (BURGER, 1990).

Unfortunately, few trees were producing seed at this time (age 12) and trials were thinned to encourage seed production. Five years after thinning, still limited seed was being produced. To capture the selections before the trials were felled, scion material was collected from the best individual from 30 families for grafting and seed for subsequent progeny testing was later collected from each grafted clone.

\section{4 trial series}

A second $E$. fastigata breeding trial series was established in 1994 with material from an additional 60 families selected from natural stands in Australia and 113 families obtained from the South African breeding programme. The Australian families were divided into five provenance groupings based on latitude and altitude. These 173 open-pollinated families were split into six sublines, to reduce inbreeding by maintaining distinct populations which could be used to make unrelated crosses later in the breeding programme. Sublines were planted adjacent to each other separated by a $40 \mathrm{~m}$ buffer of Eucalyptus nitens to prevent outcrossing between sublines. There is no replicate linkage across sublines.

The trials were established on two sites in New Zealand's North Island, at Kakarihi Road $\left(38^{\circ} 25^{\prime} \mathrm{S} 175^{\circ} 58^{\prime} \mathrm{E}\right)$ and Tylees (38 $\left.37^{\prime} \mathrm{S} 176^{\circ}{ }^{19} \mathrm{E} \mathrm{E}\right)$ (Table 1). Kakarihi Road was planted in 1994, and established primarily as a Forward Selection Plot (FSP) trial design, with eight-tree row plots replicated six times. At age five each row plot was thinned by $50 \%$ to leave the four best individuals in each plot. Tylees was planted in 1995 with most of the same families present at Kakarihi Road. These were set out as a STP design replicated 40 times to better predict the best ranked families, from which the best individuals were selected from the FSP trial. Two control seedlots from native Australian stands (Barrington Tops and Rossi) were also included in each trial. Trials were assessed at age seven for diameter, stem form, stem malformation and branching (Table 2). The original analysis of the 1994 trials selected families with breeding values greater than the population aver-

Table 1. - Site information.

\begin{tabular}{lllll}
\hline $\begin{array}{l}\text { Site } \\
\text { information }\end{array}$ & Kaingaroa & Kinleith & Kakarihi Rd. & Tylees \\
\hline Date planted & 1979 & 1979 & 1994 & 1995 \\
Latitude (S) & $38^{\circ} 27^{\circ}$ & $38^{\circ} 17^{\circ}$ & $38^{\circ} 25^{\prime}$ & $38^{\circ} 37^{\prime}$ \\
Longitude (E) & $176^{\circ} 42^{\circ}$ & $176^{\circ} 00^{\circ}$ & $175^{\circ} 58^{\prime}$ & $176^{\circ} 19^{\prime}$ \\
Altitude (m) & 270 & 490 & 270 & 530 \\
Soil & $15 \mathrm{~cm}$ soil over & Loam over & Taupo pumice & Taupo pumice \\
& rhyolite ash & volcanic ash & $/$ ash & $/$ ash \\
Slope & $2-11^{\circ}$ & $3-14^{\circ}$ & $0-5^{\circ}$ & $0-5^{\circ}$ \\
Spacing & $3 \times 2.5 \mathrm{~m}$ & $3 \times 3 \mathrm{~m}$ & $3 \times 4.5 \mathrm{~m}$ & $3 \times 4.5 \mathrm{~m}$ \\
No. of families & 126 & 126 & 173 & 141 \\
Design* & $\mathrm{STP} 3 \mathrm{sets}$ & STP $3 \mathrm{sets}$ & 8 tree row plot & $\mathrm{STP} 5$ sublines \\
Replicates & 42 & 42 & 6 & 40 \\
\hline
\end{tabular}

${ }^{*}$ STP $=$ single tree plot.

Table 2. - Trait description and abbreviations.

\begin{tabular}{ll}
\hline Trait description & Abbreviation \\
\hline Height $(\mathrm{m})$ & HTD \\
Diameter at breast height $(\mathrm{cm})$ & DBH \\
Stem straightness $1=$ highly sinuous $9=$ straight & STR \\
Form score $1=$ multileader $9=$ good stem, light branching & FRM \\
Malformation score $1=$ multiple forking to $9=$ single stem & MAL \\
Branching score $1=$ heavy branching to $9=$ light, fine branching & BRH \\
\hline
\end{tabular}


age for $\mathrm{DBH}$ and malformation, the best individual from each of these families was selected for inclusion in the breeding population.

\section{Statistical analysis}

The two series of genetic trials (1979 and 1994 Series) were analysed independently as there were no families in common between series. Moreover, each Series was of a different design requiring a separate mixed model for analysis. Additional terms were added to the models until there was no significant improvement in the log likelihood based on a chi square test. The additive variance was calculated for the individuals in each trial series using a pedigree that included a group effect to differentiate provenances. Mixed models 1 and 2 were solved using ASReml-3 (GILMOUR et al., 2009). Equivalent models without the pedigree effect were used to calculate the least square means for provenances across each trial series using SAS (9.2).

$$
1979 \text { trials } \quad \mathbf{y}=\mathbf{X b}+\mathbf{Z}_{\mathbf{1}} \mathbf{a}+\mathbf{Z}_{\mathbf{2}} \mathbf{r}+\mathbf{e}
$$

where: $\mathbf{y}$ is the vector of observations on a trait, $\mathbf{b}$ is a vector of fixed effects (i.e., site and mean), $\mathbf{a}$ is a vector of random additive genetic effects of individual genotypes (provenance was accounted for as genetic groups in the pedigree file), $\mathbf{r}$ is a vector of random replicate effects, and $\mathbf{e}$ is a vector of random residual effects. All model terms were site-specific with an independent error term calculated for each site. Set effects were insignificant and not included in Model 1. X, $\mathbf{Z}_{1}$ and $\mathbf{Z}_{2}$ are known incidence matrices relating the observations in $\mathbf{y}$ to effects in $\mathbf{b}, \mathbf{a}$ and $\mathbf{r}$ respectively.

$$
1994 \text { trials } \quad \mathbf{y}=\mathbf{X b}+\mathbf{Z}_{\mathbf{1}} \mathbf{a}+\mathbf{Z}_{\mathbf{2}} \mathbf{r}+\mathbf{Z}_{\mathbf{3}} \mathbf{p}+\mathbf{e}
$$

where: $\mathbf{y}$ is the vector of observations on a trait, $\mathbf{b}$ is a vector of fixed effects including site, subline and mean, a is a vector of random additive genetic effects of individual genotypes (provenance was accounted for in the genetic group model incorporated in the pedigree file fitted), $\mathbf{r}$ is a vector of random replicate effects within subline, $\mathbf{p}$ is a vector of random plot effects and $\mathbf{e}$ is a vector of random residual effects. All model terms were sitespecific with an independent error term calculated for each site. $\mathbf{X}, \mathbf{Z}_{1}, \mathbf{Z}_{2}$ and $\mathbf{Z}_{3}$ are known incidence matrices relating the observations in $\mathbf{y}$ to effects in $\mathbf{b}, \mathbf{a}, \mathbf{r}$ and $\mathbf{p}$ respectively.

Individual-site heritability and genetic correlation estimates were generated for the 1979 and 1994 trial series using the respective mixed models detailed above. Eucalyptus fastigata families originating from local landrace populations growing in New Zealand and South Africa were considered $2^{\text {nd }}$ generation material having likely already gone through some form of selection. These were analysed separately from families from native Australian stands which had only undergone one selection cycle. Individual tree-heritability $\left(h^{2}\right)$ was estimated for each trait as follows:

$$
h^{2}=\frac{\sigma_{a}^{2} \times 0.625}{\sigma_{a}^{2}+\sigma_{p}^{2}+\sigma_{e}^{2}}
$$

where $\sigma_{a}^{2}$ is the family variance, $\sigma_{p}^{2}$ is the plot variance and $\sigma^{2}$ is the error variance component. The additive variance was approximated using a coefficient ( $r$ ) of $1 / 2.5$ due to the increased propensity (30\%) of eucalypts to self pollinate (GRIFFIN and COTTERILL, 1988). Between family variance estimates were multiplied by 0.625 to account for the coefficient of relationship (ie.2.5/4=0.625). Genetic correlations were estimated between traits as:

$$
r_{x y}=\frac{\sigma_{x y}^{2}}{\sqrt{\sigma_{x}^{2} \times \sigma_{y}^{2}}}
$$

where $\sigma_{x y}^{2}$ is the covariance between traits $\mathrm{x}$ and $\mathrm{y}$ and $\sigma_{x}^{2}$ and $\sigma_{y}^{2}$ are the family variance for each trait. Type B (between site) genetic correlations were estimated, for each trial series, using a univariate multi-site model assuming heterogeneous variance (using CORGH, within ASReml).

\section{Selection of the next generation}

To assess the level of genetic gain that was captured from the original analyses and selection process, versus theoretical gain that was possible, hypothetical selections for both the 1979 and 1994 series were made using individual tree breeding values. For the new 1979 series analyses, families with a breeding value greater than the population average for both DBH11 and FRM11 were selected. The best individual in each of these families was then selected based on variable culling levels for DBH11, FRM11 and STR11, with all forked trees culled. The threshold for selection amongst these traits was increased until it was possible to select the best individual combining all three traits. Selections were made using independent culling as opposed to index selection due to the absence of meaningful economic weights. In total 42 families were actually selected and represented by up to three individuals, compared to the best individual from 47 families for hypothetical selections.

A similar strategy was adopted for selections from the 1994 series except the best families were selected based upon DBH07 and MAL07 and the best individual within families were selected based on a combination of MAL07, BRH07, STR07 and DBH07 using independent culling as above. Using this method, the top families were dominated by improved South African material. To increase genetic diversity, the top 19 families from the first generation Australian material were also included in the hypothetical selected population despite generally being poorer than the population mean.

The original selections made were compared with the estimated breeding values from the 'hypothetical selections' made using the results of the current analyses. For selections from the 1994 series sufficient information to identify which tree was selected was only present in $2 / 3^{\text {rd }}$ of the cases. The genetic gain from the breeding values of the original selections was compared with the genetic gain obtained from the hypothetical selections. 
Genetic gain was estimated as the percentage increase of the average of the selected population's BLUP predictions relative to the population mean.

\section{Results and Discussion}

\section{9 trial series}

The provenance least squares means across the two sites from the 1979 series are presented in Table 3 . The Oberon provenance ranked best overall for $\mathrm{DBH}$ at age five followed closely by Barrington Tops, Oakura and Natala. Natala had the best form and straightness. The provenance rankings changed little between age five and age 11 measurements. Despite being considered $2^{\text {nd }}$ generation material, the generally low ranking of the
New Zealand populations suggests that, although recent selection criteria are known, the Australian provenances were inferior or that the parentage was limited and led to inbreeding depression.

The heritability estimates for all traits were quite low, generally less than 0.2 (Figure 1). On average, traits assessed at Kaingaroa had slightly higher heritabilities compared to the same traits measured at Kinleith. The New Zealand families higher heritability estimates compared with the Australian families measured at both sites were particularly pronounced for HTD05 and DBH05. DBH and stem form were both measured age five and 11, the heritability of these two traits increased with age at Kaingaroa. At Kinleith this was only the case for the Australian families.

Table 3. - Provenance least squares means across the 1979 trial series, across site heritabilities and percentage genetic gain relative to the population mean of the best individual selected within the best families. The gain from what was actually selected and the hypothetical gain are presented. The least squared means for provenances represented by less than 4 families are omitted from this table. Averages followed by the same value do not differ significantly $(p>0.05)$.

\begin{tabular}{llllllll}
\hline Country & Provenance & $\begin{array}{l}\text { HTD05 } \\
(\mathrm{m})\end{array}$ & $\begin{array}{l}\text { DBH05 } \\
(\mathrm{cm})\end{array}$ & $\begin{array}{l}\text { STR05 } \\
1-9^{*}\end{array}$ & $\begin{array}{l}\text { FRM05 } \\
1-9^{*}\end{array}$ & $\begin{array}{l}\text { DBH11 } \\
(\mathrm{cm})\end{array}$ & $\begin{array}{l}\text { FRM11 } \\
1-9^{*}\end{array}$ \\
\hline Australian & Barrington Tops & $6.3 \mathrm{de}$ & $9.6 \mathrm{ab}$ & $6.3 \mathrm{ab}$ & $5.8 \mathrm{~d}$ & $19.7 \mathrm{bc}$ & $6.0 \mathrm{ab}$ \\
& Bombala & $7.0 \mathrm{ab}$ & $8.9 \mathrm{def}$ & $5.8 \mathrm{~cd}$ & $6.0 \mathrm{bcd}$ & $18.4 \mathrm{~d}$ & $5.9 \mathrm{ab}$ \\
& Oberon & $6.9 \mathrm{bc}$ & $9.9 \mathrm{a}$ & $5.9 \mathrm{bc}$ & $5.8 \mathrm{~cd}$ & $21.1 \mathrm{a}$ & $5.9 \mathrm{ab}$ \\
& Robertson & $6.7 \mathrm{c}$ & $8.3 \mathrm{gh}$ & $5.4 \mathrm{de}$ & $5.8 \mathrm{bcd}$ & $18.4 \mathrm{~d}$ & $5.3 \mathrm{de}$ \\
& Rossi & $7.2 \mathrm{a}$ & $9.2 \mathrm{bcde}$ & $5.5 \mathrm{de}$ & $6.1 \mathrm{abc}$ & $20.0 \mathrm{~b}$ & $5.8 \mathrm{bc}$ \\
New Zealand & Cambridge & $6.9 \mathrm{abc}$ & $9.0 \mathrm{cdef}$ & $5.6 \mathrm{cde}$ & $6.1 \mathrm{abcd}$ & $18.6 \mathrm{~cd}$ & $5.8 \mathrm{abcd}$ \\
& Hunterville & $6.9 \mathrm{abc}$ & $8.9 \mathrm{def}$ & $4.7 \mathrm{f}$ & $5.8 \mathrm{~cd}$ & $18.0 \mathrm{de}$ & $5.1 \mathrm{e}$ \\
& Kaingaroa & $6.3 \mathrm{de}$ & $7.9 \mathrm{~h}$ & $5.2 \mathrm{def}$ & $6.3 \mathrm{ab}$ & $14.8 \mathrm{f}$ & $4.9 \mathrm{e}$ \\
& Oakura & $7.3 \mathrm{a}$ & $9.5 \mathrm{abc}$ & $5.1 \mathrm{ef}$ & $5.9 \mathrm{bcd}$ & $20.2 \mathrm{ab}$ & $5.5 \mathrm{cde}$ \\
& Rotorua & $6.7 \mathrm{~cd}$ & $8.7 \mathrm{efg}$ & $5.2 \mathrm{def}$ & $5.8 \mathrm{bcd}$ & $17.8 \mathrm{de}$ & $5.3 \mathrm{de}$ \\
& Tikitere & $6.0 \mathrm{e}$ & $8.2 \mathrm{fgh}$ & $5.9 \mathrm{abcd}$ & $5.7 \mathrm{bcd}$ & $16.2 \mathrm{ef}$ & $5.7 \mathrm{abcde}$ \\
South Africa & Natal & $6.7 \mathrm{bc}$ & $9.4 \mathrm{abcd}$ & $6.5 \mathrm{a}$ & $6.4 \mathrm{a}$ & $19.9 \mathrm{abc}$ & $6.3 \mathrm{a}$ \\
\hline Across site $\mathrm{h}^{2}$ & Australian & 0.12 & 0.04 & 0.20 & 0.10 & 0.09 & 0.24 \\
& & $(0.03)$ & $(0.02)$ & $(0.04)$ & $(0.03)$ & $(0.03)$ & $(0.05)$ \\
& New Zealand & 0.30 & 0.18 & 0.25 & 0.16 & 0.25 & 0.24 \\
& & $(0.07)$ & $(0.05)$ & $(0.06)$ & $(0.05)$ & $(0.06)$ & $(0.06)$ \\
\hline Gain $(\%)$ & Hypothetical & 6.4 & 9.4 & 11.2 & 1.0 & 16.7 & 15.8 \\
& Selected & 8.9 & 8.9 & 7.2 & 1.4 & 15.8 & 12.2 \\
\hline
\end{tabular}

* $=1$ to 9 score, 1 being the worst and 9 being the best.

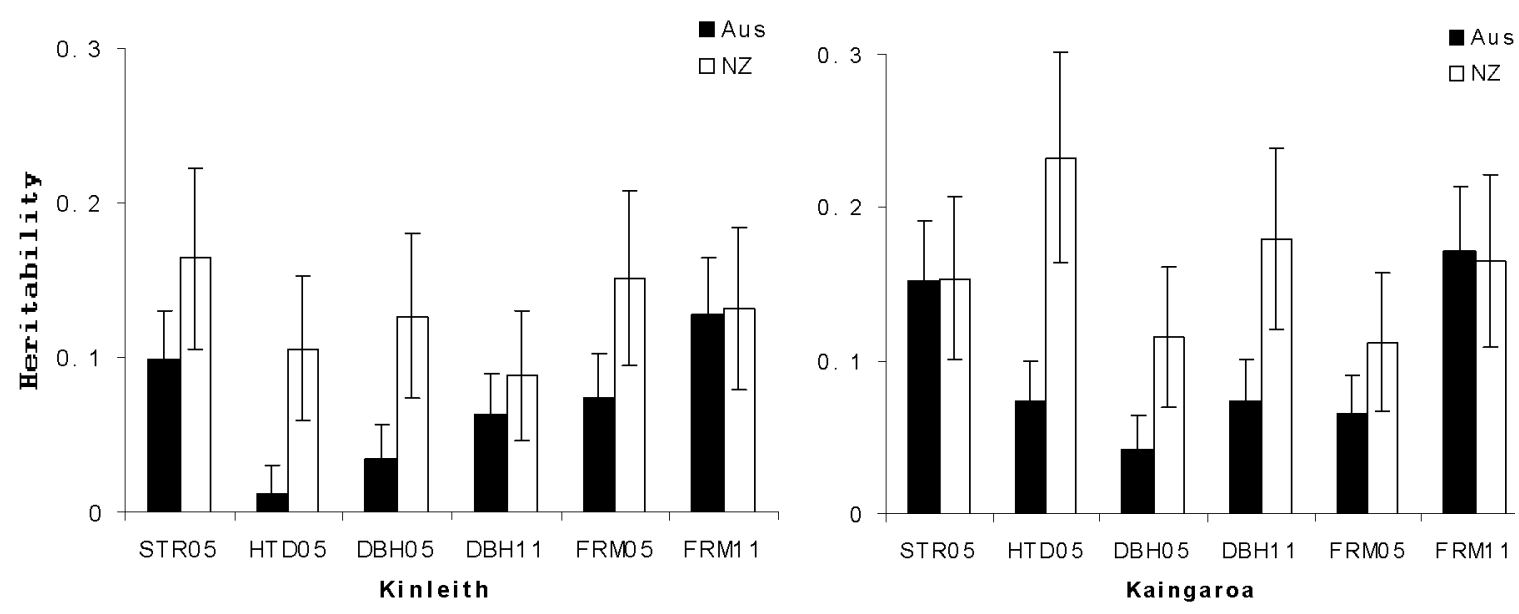

Figure 1. - Heritability of the Australian native population versus the New Zealand local land race population at the two sites, standard errors are also displayed. 
Genetic correlations between traits were strong among growth traits DBH05, DBH11 and HTD05 across sites and country of origin, as were correlations between FRM05 and FRM11 (Table 4). The strong age:age correlations (age five to 11) for FRM and DBH confirm the suitability of early selection for these traits. The pattern of genetic correlations between stem straightness and form with tree height and diameter was not clear. However, the Australian families present at Kaingaroa generally had negative correlations between these traits despite the positive correlation between these traits and the other genetic groups assessed (Table 4). Type 'B' genetic correlation between the two sites were high for all traits (HTD05 0.98, DBH05 0.88, STR05 0.89, FRM05 restrained, DBH11 0.91, FRM11 0.89), indicating little genotype by environment variation $(\mathrm{G} \times \mathrm{E})$.

The predicted gain for DBH11 and FRM11 from the hypothetical selections was $17 \%$ and $16 \%$, respectively, which is only marginally greater than the gain predicted from the actual selections made (15\% and 12\%) (Table 3 ). An increase in gain for stem straightness from $7 \%$ to $11 \%$ was also estimated based on the new hypothetical selections. Despite differing selection methods the gain was similar between hypothetical and actual selections, giving confidence to the selections made in the original analysis.

\section{4 trial series}

The provenance least squares means across the two sites from the 1994 series are presented in Table 5 . Bombala was by far the fastest growing provenance, but was amongst the poorest for form and branching. Jessievale was one of the next fastest growing provenances and had the best form and branching. Of the two unimproved control seedlots planted Rossi was the fastest growing having a comparable growth rate to the improved material. Rossi did not however share the superior stem form and branching of many of the improved provenances tested. No control seedlots were planted in the 1979 trial series preventing any comparison between genetic gains and family performance form the 1979 and 1994 trial series.

The heritability estimates from Kakarihi road and Tylees were all low (Figure 2), with the exception of the Australian families assessed for STR07, which were moderately heritable (0.41). There was no discernable trend in heritability between the Australian and South African families, although the heritability of the South African material was higher for DBH07, and heritability for form was generally higher for the Australian material.

Genetic correlations among traits were strongest for the Australian seedlots, especially those located at Kakarihi road (Table 6). Improvements in STR07 and MAL07 were associated with improvements in DBH07. Stem branching was unfavourably correlated with DBH07 for the South African families but displayed a moderate positive correlation (0.53) with the Australian families at Kakarihi road.

Genetic correlations between the two sites were strong for DBH07 (0.96), BRH07 (0.87) and STR07 (0.84). MAL07 showed a weaker correlation between sites (0.49), indicating some potential $\mathrm{G} \times \mathrm{E}$ issues if selecting for this trait across sites; however, this result is likely confounded with the Kakarihi road trial which initially suffered some leader die-back due to drift from the preplant spraying of an adjacent plot. To maintain some uniformity it was decided to form-thin the trial aged two. MAL07 was not assessed until after these events, making it difficult to draw comparisons between the two sites.

As described for the 1979 trial series, hypothetical gains were compared with what was actually selected (Table 5). The gain for MAL07 increased from $12 \%$ to $18 \%$ comparing selected with hypothetical gains. However, this increase in MAL07 is associated with a slight drop in the gain for DBH07 from $8 \%$ to $5 \%$ when com-

Table 4. - Genetic correlations between traits (standard errors are in parentheses) estimated separately for the Australian native population and New Zealand exotic population at two sites - Kaingaroa and Kinleith.

\begin{tabular}{llllll}
\hline & & Kaingaroa & & Kinleith & \\
Trait A & Trait B & NZ & Aust & NZ & Aust \\
\hline DBH05 & DBH11 & $0.92(0.06)$ & REST & REST & $0.77(0.30)$ \\
& HTD05 & $0.90(0.05)$ & $0.68(0.15)$ & $0.69(0.15)$ & $0.70(0.28)$ \\
& FRM05 & $0.31(0.28)$ & $-0.33(0.29)$ & $-0.03(0.33)$ & REST \\
& FRM11 & $0.53(0.23)$ & $-0.04(0.27)$ & $0.48(0.28)$ & REST \\
& STR05 & $0.46(0.23)$ & $-0.48(0.26)$ & $0.19(0.29)$ & REST \\
DBH11 & HTD05 & $0.87(0.07)$ & $0.78(0.11)$ & $0.84(0.09)$ & $0.56(0.24)$ \\
& FRM05 & $0.39(0.26)$ & $-0.03(0.26)$ & $0.13(0.33)$ & $0.78(0.46)$ \\
& FRM11 & $0.61(0.18)$ & $0.08(0.22)$ & $0.47(0.27)$ & $0.76(0.29)$ \\
& STR05 & $0.70(0.18)$ & $-0.27(0.22)$ & $0.30(0.27)$ & $0.46(0.34)$ \\
HTD05 & FRM05 & $0.59(0.20)$ & $-0.19(0.27)$ & $0.35(0.31)$ & $0.72(0.29)$ \\
& FRM11 & $0.52(0.20)$ & $-0.02(0.21)$ & $0.53(0.25)$ & $0.56(0.22)$ \\
& STR05 & $0.58(0.18)$ & $-0.33(0.22)$ & $0.19(0.26)$ & $0.38(0.25)$ \\
FRM05 & FRM11 & $0.75(0.17)$ & $0.85(0.14)$ & $0.91(0.18)$ & $0.69(0.18)$ \\
& STR05 & $0.90(0.12)$ & REST & $0.83(0.14)$ & REST \\
FRM11 & STR05 & REST & $0.91(0.07)$ & REST & $0.90(0.11)$ \\
\hline
\end{tabular}

REST $=$ correlation restrained i.e. out with the bounds of -1 to 1 . 
Table 5. - Provenance least squares means across the 1994 trial series, across site heritabilities and percentage genetic gain (\%) relative to the population mean of the best individual selected within the best families. The gain from what was actually selected and the hypothetical gain are presented. Averages followed by the same value do not differ significantly $(p>0.05)$.

\begin{tabular}{llllll}
\hline Country & Provenance & $\begin{array}{l}\text { DBH07 } \\
(\mathrm{cm})\end{array}$ & $\begin{array}{l}\text { MAL07 } \\
1-9^{*}\end{array}$ & $\begin{array}{l}\text { BRH07 } \\
1-9^{*}\end{array}$ & $\begin{array}{l}\text { STR07 } \\
1-9^{*}\end{array}$ \\
\hline Australia & Barrington Tops & $22.0 \mathrm{a}$ & $5.3 \mathrm{bc}$ & $5.3 \mathrm{~b}$ & $5.6 \mathrm{abc}$ \\
& Bombala & $23.1 \mathrm{ab}$ & $5.2 \mathrm{abc}$ & $4.2 \mathrm{bc}$ & $4.5 \mathrm{abc}$ \\
& Glenbog & $21.6 \mathrm{a}$ & $4.9 \mathrm{c}$ & $4.9 \mathrm{bc}$ & $5.4 \mathrm{abc}$ \\
& Oberon & $21.6 \mathrm{ab}$ & $4.8 \mathrm{abc}$ & $5.0 \mathrm{abc}$ & $4.9 \mathrm{bc}$ \\
& Tallaganda & $22.4 \mathrm{ab}$ & $4.5 \mathrm{bc}$ & $4.6 \mathrm{bc}$ & $5.0 \mathrm{bc}$ \\
South Africa & Eastern Transvaal & $21.8 \mathrm{a}$ & $5.5 \mathrm{~b}$ & $5.2 \mathrm{~b}$ & $5.8 \mathrm{ab}$ \\
& Jessievale & $22.2 \mathrm{a}$ & $5.9 \mathrm{a}$ & $5.7 \mathrm{a}$ & $5.9 \mathrm{a}$ \\
Controls & Barrington Tops & $19.7 \mathrm{~b}$ & $5.3 \mathrm{abc}$ & $5.5 \mathrm{ab}$ & $5.9 \mathrm{ab}$ \\
& Rossi & $23.0 \mathrm{a}$ & $4.7 \mathrm{bc}$ & $4.3 \mathrm{c}$ & $4.8 \mathrm{c}$ \\
\hline \multirow{2}{*}{ Across site } & Australian & 0.33 & 0.23 & 0.22 & 0.58 \\
heritability & & $(0.08)$ & $(0.06)$ & $(0.06)$ & $(0.11)$ \\
& South African & 0.35 & 0.16 & 0.27 & 0.35 \\
& & $(0.05)$ & $(0.03)$ & $(0.04)$ & $(0.05)$ \\
\hline \% Gain & Hypothetical & 4.7 & 18.3 & 8.4 & 3.8 \\
& Selected & 7.9 & 12.0 & 7.9 & 1.0 \\
\hline
\end{tabular}

* $=1$ to 9 score, 1 being the worst and 9 being the best.
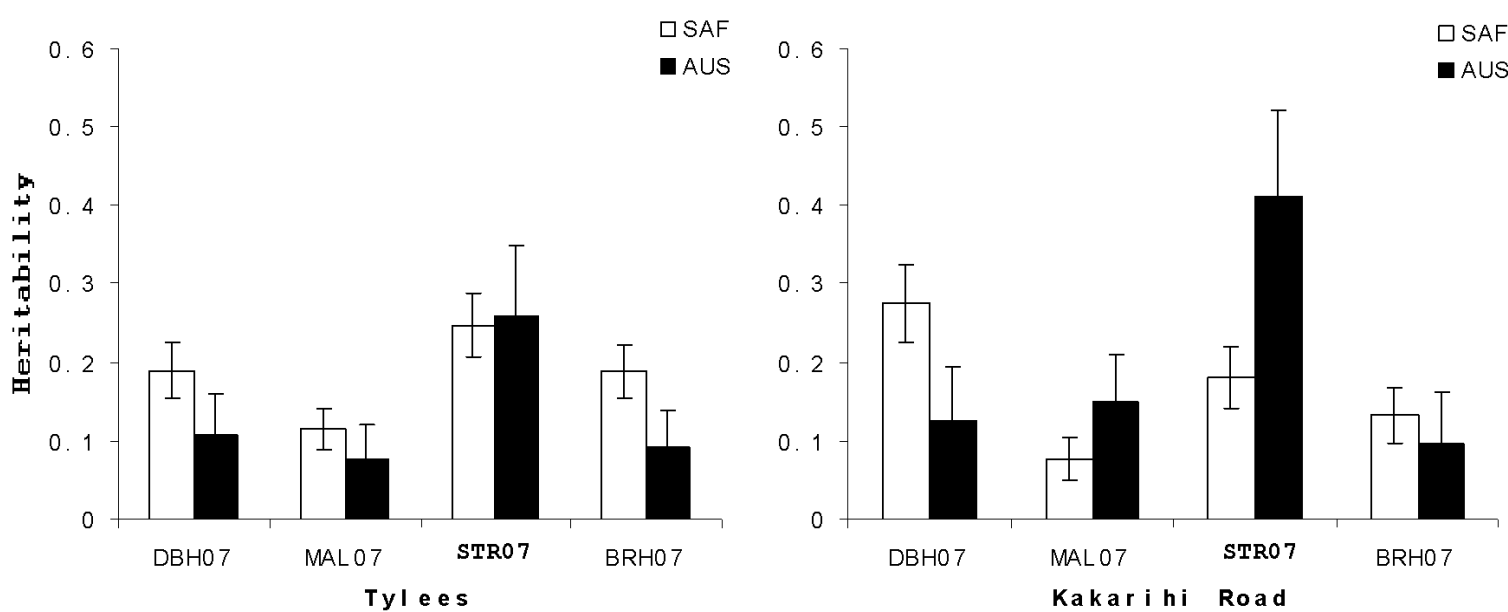

Figure 2. - Heritability of the Australian native population versus the South African local land race population at the two sites, standard errors are also displayed.

paring selected with hypothetical gains. This reduction in DBH07 could in part be due to the greater proportion of poorer Australian families included in the hypothetical selections $\left(1 / 3^{\text {rd }}\right)$, to maintain genetic diversity, compared to the proportion of Australian families in the actual selections made $\left(1 / 7^{\text {th }}\right)$.

The use of two trial designs STP and FSP were adopted in the 1994 trial series. The STP design was intended to enable accurate ranking of family means across sets, whilst the FSP design, consisting of family row plots, simplifies selection of the best individual within each family. Roguing within the family rows also encourages crown development and seed production (CANNON and SHELbOURNE, 1993). The additive variance was lower in the FSP design compared to the STP design. However, a direct comparison of the two tests is not appropriate given that the plots within the FSP trial were rogued by $50 \%$ at the time of assessment resulting in greater family uniformity and likely leading to the lower additive variation expressed.

\section{Issues to date with the breeding programme}

The origin and selection criteria of seed collection of the initial introductions of E. fastigata to New Zealand from Australia in the 1880's are not documented. Second generation material from New Zealand populations would have been assumed to perform well having acclimatised with plus-tree selection based upon performance under local environmental conditions. However, the plus trees from these initial stands of unknown origin, once tested alongside native Australian material and material from the South African breeding pro- 
Table 6. - Genetic correlations between traits (standard errors are in parentheses) estimated separately for the Australian native population and South African exotic population at two sites - Tylees and Kakarihi.

\begin{tabular}{llllll}
\hline & & Tylees & & Kakarihi & \\
Trait A & Trait B & S Africa & Aust & S Africa & Aust \\
\hline DBH07 & MAL07 & $0.11(0.15)$ & $0.60(0.34)$ & $0.25(0.18)$ & $0.81(0.36)$ \\
& STR07 & $0.28(0.12)$ & $0.20(0.30)$ & $0.18(0.15)$ & $0.81(0.23)$ \\
& BRH07 & $-0.30(0.13)$ & $0.03(0.38)$ & $-0.27(0.15)$ & $0.53(0.45)$ \\
MAL07 & STR07 & $0.47(0.12)$ & $0.95(0.14)$ & $0.65(0.14)$ & $0.76(0.15)$ \\
& BRH07 & $0.48(0.13)$ & $0.11(0.39)$ & $0.59(0.17)$ & $0.91(0.31)$ \\
STR07 & BRH07 & $0.34(0.12)$ & $0.32(0.29)$ & $0.36(0.15)$ & $0.66(0.23)$ \\
\hline
\end{tabular}

gramme, were generally found to be inferior. One of two conclusions may be drawn from this; either the selection criteria of the initial seed was much lower than that of material from South Africa and Australia, or the genetic base of the initial New Zealand populations was limited, perhaps originating from just a few trees, leading to inbreeding depression and a subsequent loss of performance.

The other main issue encountered was lack of seed production in the 1979 trial series which slowed breeding cycle turn-around considerably. The trials were retained at their original stocking of 1111 stems per hectare, leading to strong competition and resulted in the formation of small restricted crowns. While the trials were later thinned around putative selections to encourage crown development and seed production, the response was limited. In order to capture these selections a grafted seed orchard was established. Sufficient seed from selections was eventually obtained, but was not planted out into trials until 2010, unfortunately a full 30 years after the first progeny tests were planted.

It is proposed in the New Zealand breeding plan (Low et al., 2009) for E. fastigata, that a rolling front strategy (BorRALHO and DuTKOWsKI, 1998), be adopted to speed up the turn around of breeding cycle. Such a strategy would involve the planting out of smaller trials if and when seed becomes available instead of waiting for all selections to have produced seed. This strategy has been shown to result in increased gains over time mainly due to reduced generation intervals. Provided sufficient overlap exists between trials, it is expected that the prediction of breeding values across generations using REML/BLUP analysis would not disadvantage the rolling front scenario over conventional methods (BoRRALHO and DUTKOWSKI, 1998).

\section{The future of E. fastigata tree breeding in New Zealand}

Eucalyptus fastigata is a minor commercial species in New Zealand, therefore it is likely future generations of the breeding programme will rely on open-pollinated breeding to minimise costs. The genetic base generated from these two series of trials likely provides an adequate population to continue long-term breeding. Unless $E$. fastigata trials are adjacent to other stands of $E$. fastigata, it can be assumed that the pollen parent has come from within the breeding population. DNA markers can be used to identify the parents of an indi- vidual if they are known to have come from a specific population (LAMBETH et al., 2001). Pedigree reconstruction using genetic finger printing is a relatively inexpensive method for increasing potential gain and controlling levels of inbreeding, avoiding the need to maintain discreet population sub-lines (EL-KASSABY and LSTIBUREK, 2009; LAMBETH et al., 2001). The technique has been successfully used with many other eucalypt species (GEA et al., 2007; KIRST et al., 2005; NESBITT et al., 1997) and is currently being developed for use with $E$. fastigata.

Eucalyptus fastigata has predominantly been targeted for pulp production in the past. Recent sawing studies (JONES et al., 2010) have shown that the species produces high-quality timber. There has been increasing interest in planting this species to qualify for carbon credits due to its comparable growth rate to Pinus radiata and higher density. Consequently, short rotations for pulp may be less favourable with the interest in retaining crops for longer periods of time in order to maximise carbon sequestration. This may lead to a shift away from pulp production to increased timber production. The initial generation of the breeding programme has concentrated on genetically improving form characteristics of this species whilst selecting for growth. In subsequent generations, greater emphasis will be placed upon key mechanical properties, whether for pulp or timber production, whilst continuing to improve tree form. Eucalyptus fastigata is currently capable of achieving loadbearing structural machine stress grades (MSG 10-15) and is not considered stiffness limited (JONES et al., 2010), making structural timber the logical end product for long rotation stands initially planted for carbon forestry.

\section{Acknowledgements}

The author would like to thank all those previously involved in the $E$. fastigata breeding programme. Special mention should go to M. D. WilCOX, C. J. A. SHELBOURNE and R. MCCONNOCHIE who were instrumental in the initiation and running of the breeding programme.

\section{References}

Borralho, N. M. G. and G. W. DutKowski (1998): Comparison of rolling front and discrete generation breeding strategies for trees. Canadian Journal of Forest Research 28(7): 987-993. 
BuRger, F. C. (1990): Provenance, family and individual plus tree selection in an 11 year old $E$. fastigata progeny/provenance trial. Eucalypt breeding cooperative report, Rotorua, New Zealand.

Cannon, P. G. and C. J. A. Shelbourne (1993): Forward selection plots in breeding programmes with insectpollinated tree species. New Zealand Journal of Forest Science 23(1): 3-9.

El-Kassaby, Y. A., T. Funda and B. S. K. LAI (2010): Female reproductive success variation in a pseudotsuga menziesii seed orchard as revealed by pedigree reconstruction from a bulk seed collection. Journal of Heredity 101(2): 164-168.

EldRIDGe, K., J. Davidson, C. Harwood and G. V. WYK (1993): Eucalypt domestication and breeding. Clarendon Press, Oxford.

Griffin, A. R. and P. P. CotTerill (1988): Genetic variation in growth of outcrossed, selfed and open-pollinated progenies of Eucalyptus regnans and some implications for breeding strategy. Silvae Genetica 37: 124-131.

Jones, T. G., R. M. McConnochie, C. J. A. Shelbourne and C. B. Low (2010): Sawing and grade recovery of 25-yearold Eucalyptus fastigata, E. globoidea, E. muelleriana and $E$. pilularis. New Zealand Journal of Forest Science 40: $19-31$.

GEA, L. D., R. M. McConnochie and S. WynyaRD (2007): Parental reconstruction for breeding, deployment, and seed-orchard management of Eucalyptus nitens. New Zealand Journal of Forest Science 37(1): 23-36.
Gilmour, A. R., B. J. Gogel, B. R. Cullis and R. Thompson (2009): ASReml User Guide Release 3.0 VSN International Ltd, Hemel Hempstead, HP1 1ES, UK. www.vsni.co.uk.

Kirst, M., C. M. Cordeiro, G. D. S. P. Rezende and D. GRATTAPAGLiA (2005): Power of microsatellite markers for fingerprinting and parentage analysis in Eucalyptus grandis breeding populations. Journal of Heredity 96(2): 161-166.

Lambeth, C., B. C. Lee, D. O'Malley and N. Wheeler (2001): Polymix breeding with parental analysis of progeny: An alternative to full-sib breeding and testing. Theoretical and Applied Genetics 103(6-7): 930-943.

Low, C., H. Dungey, T. Stovold and I. Nicholas (2009): A breeding plan for New Zealand Eucalyptus fastigata. FFR Internal Report, SCION, New Zealand.

Nesbitt, K. A., B. M. Potts, R. E. Vaillancourt and J. B. REID (1997): Fingerprinting and pedigree analysis in Eucalyptus globulus using RAPDs. Silvae Genetica 46(1): 6-11.

WILCOX, M. D. (1980): Genetic improvement of eucalypts in New Zealand. New Zealand Journal of Forest Science 10(2): 343-359.

WILCOX, M. D. (1982): Genetic variation in frost tolerance, early height growth, and incidence of forking among and within provenances of Eucalyptus fastigata. New Zealand Journal of Forest Science 12(3): 510-524.

\title{
Threshold selection for rust resistance in hybrid poplar: Population response to mass selection
}

\author{
By B. J. STANTON*
}

(Received $1^{\text {st }}$ February 2011)

\begin{abstract}
Eleven Populus $\times$ generosa populations were developed in the Pacific Northwest by annual controlled hybridization of P.deltoides and P.trichocarpa between 1991 and 2001. Mass selection for Melampsora leaf rust resistance was observed in the field as a threshold character in identifying seedling phenotypes for clonally replicated evaluation. The effectiveness of the approach was assessed for each annual population by comparing the distribution of phenotypes in unselected seedling populations with the distribution of selected genotypes in the clonal field tests established in successive years and evaluated at the approximate same level of disease severity using two selection thresholds corresponding to chlorotic and healthy tissue. Bi-directional selection was used as an initial check on the efficacy of the procedure

\footnotetext{
*) Corresponding author: BRIAN J. StANTON. Chief Science Officer, GreenWood Resources, 1500 SW First Avenue, Portland, Oregon, U.S.A. 97201. Tel: 971-533-7052, Fax: 503-478-0751. EMail: brian.stanton@gwrglobal.com
}

and resulted in a wide separation in liability between the positive (0.06 threshold units (T.U.)) and negative (-2.45 T. U.) selection groups when tested as clones. The other 10 seedling populations that were subjected solely to directional selection exhibited a mean increase in incidence above the first selection threshold at the clonal stage (47 versus $81 \%$ ) that was accompanied by an improvement in population liability $(-0.06$ versus 0.50 T. U.) and a reduction in population standard deviation ( 0.83 versus 0.54 T.U.). The change in liability was strongly related by polynomial regression to selection intensity and a grouping of populations based on infection-season precipitation $\left(r^{2}=0.98\right)$. The mean liability of four of the 10 seedling populations observed during years of high infection-season rainfall was six-fold lower than the mean liability of those populations observed during the other six years of lower infection-season rainfall (-0.12 T. U. versus -0.02 T. U., respectively), indicating that populations undergoing evaluation during years of heavy precipitation experienced more intense rust exposure. Moreover, quadratic functions showed that 